AGRICA: Journal of Sustainable Dryland Agriculture, 14 (2): 137-145 (2021)

ISSN-Online: 2715-4955; ISSN-Cetak: 2715-6613

DOI:https://doi.org/ 10.37478/agr.v14i2.1540

\title{
ANALISIS KIMIA TANAH DAN REKOMENDASI PENINGKATAN KESUBURAN TANAH DI KEBUN PRAKTEK FAKULTAS PERTANIAN UNIVERSITAS NUSA NIPA
}

\author{
Fulgensius Sawan, Yovita Yasintha Bolly*, Almaria Heliana
}

\author{
Program Studi Agroteknologi Fakultas Pertanian Universitas Nusa Nipa Maumere \\ Jln. Kesehatan No 3.Maumere, Nusa Tenggara Timur \\ *Email: vytayovieeta@gmail.com
}

\begin{abstract}
Soil Chemical Analysis and Recommendations for Increasing Soil Fertility in Practical Gardens, Faculty of Agriculture, University of Nusa Nipa. Research on Analysis of Soil Chemical Content in the Practical Garden of the Faculty of Agriculture, University of Nusa Nipa, East Alok District, Sikka Regency has been carried out from October to December 2021. This study aims to determine the chemical content of soil in the Practical Garden of the Faculty of Agriculture, University of Nusa Nipa, East Alok District, Sikka Regency. . The research method used is observation, laboratory testing and literature study. Analysis of soil chemical content using a dry soil test device with a diagonal composite soil sampling method. The results showed that the soil in the practice garden had low organic $C$ content (1.00$2.00 \%$ ), neutral $\mathrm{pH}$ (6.5-7.5), high phosphorus content (26-35) and also Potassium content is in the moderate to low range.
\end{abstract}

Keywords : C-Organik, pH, Phosphorus, Potassium, Soil Chemical.

\section{PENDAHULUAN}

Pertanian lahan kering di Kabupaten Sikka Nusa Tenggara Timur (NTT) merupakan sistem pertanian yang sangat dipengaruhi curah hujan yang sangat rendah dengan jumlah musim hujan 8 bulan dan 4 bulan musim kemarau. Namun, hal tersebut tidak dapat menjadi faktor pembatas dalam mengembangkan kegiatan pertanian. Hampir sebagian besar penduduk Kabupaten Sikka merupakan petani lahan kering, yang selalu memanfaatkan sumberdaya alam untuk melakukan budidaya tanaman guna memenuhi kebutuhan keluarga dan masyarakat pada umumnya.

Fakultas pertanian Universitas Nusa Nipa (FP Unipa) memiliki sebuah kebun praktek lahan kering. Berbagai komoditi hortikutura dikembangkan pada kebun tersebut, antara lain bawang merah, tomat, cabe, ketimun, terung, sawi, semangka dan berbagai jenis tanaman lainnya. (Heryani dan Rejekiningrum (2019) menyatakan 
bahwa hampir sebagian besar lahan kering yang ada di NTT merupakan lahan-lahan marginal, dimana selain kekurangan air, lahan tersebut dari sisi kesuburan tanah baik kesuburan fisik, kimia dan biologi tanah sangat rendah. Hal tersebut menyebabkan perlu penambahan berbagai input pada tanah untuk dapat meningkatkan pertumbuhan dan produksi tanaman budidaya. Demikian pula pada kebun praktek Fakultas Pertanian, penambahan pupuk organik dan anorganik selalu dilakukan untuk meningkatkan kesuburan tanah.

Kesuburan tanah merupakan kemampuan suatu tanah untuk menghasilkan produk tanaman yang diinginkan, pada lingkungan tempat tanah itu berada (Hanafiah, 2012). Produk tanaman tersebut dapat berupa buah, biji, daun, bunga, umbi, akar, batang, naungan, penampilan dan sebagainya. Tanah memiliki kesuburan yang berbeda-beda, yang dipengaruholeh berbagai faktor diantaranya adalah kegiatan budidaya tanaman. Budidaya tanaman yang dilakukan secara intensif dapat mempengaruhi keseimbangan unsur hara dalam tanah, yang disebabkan oleh proses input dan output hara yang tidak seimbang oleh tanaman (Mawardiana et al., 2013). Dampak dari kegiatan pertanian yang dilakukan secara intensif dikhawatirkan justru dapat menyebabkan perubahan status kandungan kimia tanah pada kebun praktek FP Unipa. Penelitian ini bertujuan untuk mengetahui status kesuburan tanah di kebun praktek dan dapat memberikan rekomendasi dalam upaya meningkatkan kesuburan tanah.

\section{METODE DAN BAHAN \\ Tempat dan Waktu Penelitian}

Penelitian ini dilaksanakan di Kebun Praktek Fakultas Pertanian Kecamatan Alok Timur Kabupaten Sikka dan laboratorium Fakultas Pertanian Universitas Nusa Nipa Indonsia. Waktu penelitian dilaksanakan pada bulan Oktober sampai Desember 2021.

\section{Alat dan Bahan}

Alat yang dibutuhkan dalam penelitian ini, yaitu plastik, kamera, Perangkat Uji Tanah Kering (PUTK), alat tulis, cangkul dan meteran, tabung reaksi, rak penyimpanan, sendok stainless serta ember plastik.

Bahan yang digunakan dalam penelitian ini adalah sampel tanah, air, Pereaksi Perangkat Uji Tanah Kering digunakan untuk mengecek kandungan kimia tanah.

\section{Sampel Tanah}

Pengambilan sampel tanah menggunakan metode komposit secara diagonal dengan variabel yang dianalisis yaitu kadar hara $\mathrm{P}, \mathrm{K}, \mathrm{C}$-organik, $\mathrm{pH}$ tanah. 
Sawan: Analisis kimia tanah dan rekomendasi peningkatan kesuburan tanah

\section{Metode Analisis Data}

Metode analisis data yang akan digunakan adalah deskriptif kuantitatif, yaitu dengan menganalisis kandungan kimia tanah di laboratorium FP Unipa. Data hasil analisis laboratorium kemudian diolah dengan metode matching yaitu dengan membandingkan hasil analisis kandungan kimia tanah dengan standar kandungan kimia tanah menurut Pusat penelitian Tanah Bogor.

\section{HASIL DAN PEMBAHASAN Kandungan C-Organik Tanah}

Hasil analisa menunjukkan bahwa tanah pada Kebun praktek FP Unipa memiliki sebaran kriteria kandungan Corganik yang rendah yaitu berkisar $1 \%$ 2\% berdasarkan kriteria penilaian Pusat Penelitian Tanah.

\begin{tabular}{ccc}
\multicolumn{3}{c}{ Tabel 1. Hasil analisis kandungan C- } \\
Organik Tanah di Lokasi Penelitian \\
\hline No & Kode Sampel & C-Organik \\
\hline 1 & S1 & Rendah \\
2 & S2 & Rendah \\
3 & S3 & Rendah \\
4 & S4 & Rendah \\
\hline
\end{tabular}

Ket: S1- S4: Sampel tanah 1- sampel tanah 4

Kandungan bahan organik merupakan indikator paling penting dan menjadi kunci dinamika kesuburan tanah.Bahan organik mempunyai peran multifungsi, yaitu mampu merubah sifat fisik, sifat kimia dan sifat biologi tanah (Hanafiah, 2012). Kandungan bahan organik yang rendah dalam tanah pada lokasi penelitian tentunya akan berpengaruh ketiga sifat tanah tersebut. Kondisi tersebut disebabkan karena bahan organik tanah dapat memperbaiki kondisi tanah agar tidak terlalu berat dan tidak terlalu ringan dalam pengolahan tanah. Berkaitan dengan pengolahan tanah, penambahan bahan organik akan meningkatkan kemampuannya untuk diolah pada lengas yang rendah(Hanafiah, 2012). Disamping itu kandungan bahan organik dalam tanah akan memperluas kisaran kadar lengas untuk dapat diolah dengan alat-alat yang baik, tanpa banyak mengeluarkan energi akibat perubahan kelekatan tanah terhadap alat. Hasil penelitian sebelumnya yang dilakukan oleh(Gili, 2019) menunjukkan bahwa tanah pada lokasi penelitian didominasi oleh tanah lempung berpasir. tekstur lempung berpasir termasuk kelompok tekstur kasar (Hanafiah, 2012).

Tanah pasir bertekstur kasar dan sulit menyimpan air akan menjadi halus dan menyimpan air dengan adanya penambahan bahan organik. Hal ini bermanfaat untuk menghindarkan tekanan kekeringan pada tanaman.

Bahan organik juga dapat merubah sifat kimia tanah, yaitu melalui proses dekomposisi yang dilakukan oleh mikroba yang memang selalu menempel pada bahan organik. Proses dekomposisi akan melepaskan zat-zat hara ke larutan tanah dan membuat bahan organik menjadi lebih 
sederhana sehingga dapat diserap oleh tanaman. Kondisi ini akan meningkatkan kemampuan absosbsi tanah yang berkaitan juga dengan kapasitas tukar kation (KTK) tanah karena meningkatnya luas permukaan partikel tanah(Soekamto, 2015). Hal ini menjadikan tanah mempunyai kemampuan menyimpan unsur-unsur hara yang semakin baik, mengurangi penguapan nitrogen, maupun pencucian kation-kation lainnya, sehingga unsur hara akan lebih banyak diserap oleh tanaman.

Bahan organik juga mampu merubah sifat biologi tanah dengan meningkatkan populasi mikroba di dalam tanah. Populasi mikroba yang meningkat (baik jenis dan jumlahnya) menyebabkan dinamika tanah akan semakin baik dan menjadi sehat. Peningkatan mikroba akan meningkatkan kemantapan agregasi partikel-partikel penyusun tanah. Bahan organik juga berperan sebagai ZPT (Zat pengatur tumbuh), karena proses dekomposisi akan menghasilkan proses akhir berupa humus. Humus disebut juga sebagai asam humat (humic acid).Asam humat banyak dikaitkan dengan perkecambahan biji di dalam tanah, pertumbuhan bagian atas tanaman, pemanjangan semaian muda atau pemanjangan akar karena asam humat menunjukkan pengaruh hormonal dalam pertumbuhan tanaman (Hermanto et al., 2013).

\section{Kandungan Fosfor (P) Tanah}

Hasil analisa menunjukkan bahwa kandungan fosfor $(\mathrm{P})$ pada tanah memiliki kriteria yang tinggi (berkisar 26- 35 ppm) .

Tabel 2. Hasil analisis kandungan Fosfor Tanah di Lokasi Penelitian

\begin{tabular}{ccc}
\hline No & Kode Sampel & P-tanah \\
\hline 1 & S1 & Tinggi \\
2 & S2 & Tinggi \\
3 & S3 & Tinggi \\
4 & S4 & Tinggi \\
\hline
\end{tabular}

Ket: S1- S4: Sampel tanah 1- sampel tanah 4

Konsentrasi $\mathrm{P}$ yang tinggi pada tanah lokasi penelitian dapat disebabkan oleh kegiatan budidaya tanaman yang intensif. Berbagai jenis tanaman yang dibudidayakan, terutama tanaman bawang merah tentunya akan diikuti dengan penambahan aplikasi pupuk anorganik NPK phonska dan SP36.

Berbagai hasil penelitian menunjukkan bahwa jumlah fosfor yang diserap tanaman rendah yaitu hanya sekitar $15-20 \%$. Kondisi ini sering terjadi pada lahan irigasi sehingga residu fosfor didalam tanah cukup tinggi (Yusron et al., 2018). Hal tersebut disebabkan karena pergerakan $\mathrm{P}$ dalam tanah sangat lambat dan tidak mudah hilang. Selain itu P yang diserap tanaman pun dalam jumlah yang rendah (Bustami et al., 2012). Selebihnya dari P terfiksasi dan tetap tinggal di daerah perakaran dan perlahan cukup tersedia bagi tanaman, sehingga menyebabkan residu $\mathrm{P}$ tertinggal 
di dalam tanah dan lama kelamaan akan mencemari tanah dan air.

\section{Kandungan K- tanah}

Hasil analisa menunjukkan bahwa tanah lokasi penelitian memiliki kriteria konsentrasi kalium (K) tanah yang rendah sampai dengan sedang (berkisar $10 \mathrm{mg} / 100$ gr sampai dengan $20 \mathrm{mg} / 100 \mathrm{gr}$ dan 21 $\mathrm{mg} / 100$ gr sampai dengan $40 \mathrm{mg} / 100 \mathrm{gr}$ ) .

Tabel 3. Hasil analisis kandungan Kalium Tanah di Lokasi Penelitian

\begin{tabular}{ccl}
\hline No & Kode Sampel & \multicolumn{1}{c}{ K-tanah } \\
\hline 1 & S1 & Sedang \\
2 & S2 & Rendah \\
3 & S3 & Sedang \\
4 & S4 & Rendah \\
\hline
\end{tabular}

Ket: S1- S4: Sampel tanah 1- sampel tanah 4

Perbedaan konsentrasi kalium pada tanah lokasi penelitian dapat disebabkan berbagai faktor, antara lain terserap oleh tanaman dan terjadinya pencucian (leaching) pada tanah. Menurut (Wihardjaka, 2016) kahat kalium disebabkan oleh rendahnya kapasitas pasok kalium tanah, ketidakcukupan pemberian pupuk kalium anorganik, pengangkutan semua hasil panen yang tidak dimanfaatkan ke luar lahan, rendahnya efisiensi penyerapan pupuk kalium yang diberikan karena tingginya kapasitas pengikatan atau pencucian kalium.

\section{Tingkat Keasaman Tamnah (pH)}

Kemasaman tanah pada lokasi penelitian dapat dilihat pada tabel 4 .

Tabel 4. Hasil analisis kandungan pH Tanah di Lokasi Penelitian

\begin{tabular}{lcc}
\hline No & $\begin{array}{c}\text { Kode } \\
\text { Sampel }\end{array}$ & pH Tanah \\
\hline
\end{tabular}

\begin{tabular}{lll}
1 & $\mathrm{~S} 1$ & Netral (pH 6-7) \\
2 & $\mathrm{~S} 2$ & Netral (pH 6-7) \\
3 & $\mathrm{~S} 3$ & Netral (pH 6-7) \\
4 & $\mathrm{~S} 4$ & Netral (pH 6-7) \\
\hline
\end{tabular}

Ket: S1- S4: Sampel tanah 1- sampel tanah 4

Kemasaman tanah (pH) dapat menunjukkan mudah tidaknya unsur-unsur hara dalam tanah dapat di serap oleh tanaman. Hal tersebut disebabkan karena unsur hara akan lebih mudah diserap pada $\mathrm{pH}$ netral. Terdapat beberapa faktor yang menyebabkan tanah pada lokasi penelitian bereaksi netral, yaitu : (1) curah hujan yang rendah pada daerah penelitian dengan musim kemarau lebih banyak dibandingkan musim hujan, dengan curah hujan yang rendah maka secara alami tanah akan bereaksi netral karena pencucian unsur hara terjadi sangat sedikit. (2) Drainase yang baik, tanah dengan tanpa adanya genangan yang terus menerusmenyebabkan berkurangnya unsur seperti Al (alumunium), $\mathrm{Fe}$ (besi), $\mathrm{Cu}$ (tembaga) dalam keadaan yang sedikit sehingga tidak menyebabkan tanah masam. (3) Kandungan bahan organik yang rendah pada tanah. Hal itu karena proses dekomposisi bahan organik yang dalam prosesnya akan mengusir dan mengeluarkan unsur kalsium (Ca) dari dalam tanah sebagai penyumbang kemasaman pada tanah(Hanafiah, 2012). 
Rekomendasi Dalam Upaya Peningkatan Kesuburan Tanah

Beberapa rekomendasi yang dapat diberikan untuk menjaga dan meningkatkan kesuburan tanah yang pertama yaitu penambahan bahan organik secara kontinyu atau berkelanjutan pada Kebun Praktek FP UNIPA merupakan upaya yang perlu dilakukan untuk meningkatkan kandung COrganik tanah. Penggunaan berbagai jenis pupuk organik, antara lain kompos, bokasi, biochar, pupuk kandang sapi, pupuk kandang ayam, pupuk hijau dan jenis pupuk organik lainnya merupakan cara pengelolaan yang murah dan mudah. Hal tersebut karena berbagai bahan organik yang ada di sekitar kebun praktek dapat dimanfaatkan sebagai pupuk organik.

Rekomendasi berikutnya adalah Kandungan fosfor tanah yang tinggi pada lokasi penelitian menyebabkan perlu adanya pertimbangan untuk dilakukan pemupukan fosfor dalam tanah. Penambahan unsur hara yang sudah cukup tersedia justru menyebabkan masalah pencemaran lingkungan (tanah dan perairan) karena terdapat residu unsur fosfor dalam tanah. Pemupukan fosfor dalam bentuk TSP/SP36 yang berlebihan dapat mengakibatkan ketidak-seimbangan hara di dalam tanah, tidak memberikan peningkatan hasil tanaman yang nyata, efisiensi pemupukan menjadi rendah, kemungkinan unsur hara lain seperti $\mathrm{Zn}$ menjadi tidak tersedia, $\mathrm{pH}$ tanah semakin masam dan penimbunan serta kejenuhan fosfor (P) (Dharmayanti et al., 2013).

Berdasarkan hasil analisis tingkat kemasaman tanah pada lokasi penelitian sangat mendukung ketersediaan $\mathrm{P}$ bagi tanaman. Ketersediaan $\mathrm{P}$ akan menurun bila pH tanah lebih rendah dari 7,0 atau lebih tinggi dari 7,0. Hal ini didukung oleh hasil penelitian yang telah dilakukan (Suarjana et al., 2016)yang menunjukkan bahwa semakin netral $\mathrm{pH}$ tanah, maka kondisi $\mathrm{P}$ tersedia tanah semakin tinggi.Selain $\mathrm{pH}$, kandungan $\mathrm{P}$ tersedia tanah juga ditentukan oleh C-Organik Tanah.

Kandungan C-organik yang rendah pada lokasi penelitian dapat menyebabkan kandungan $\mathrm{P}$ dalam tanah tinggi, namun $\mathrm{P}$ yang tersedia dalam larutan tanah sehingga dapat diserap oleh akar tanaman rendah. Karena, apabila kandungan C-organik di dalam tanah tinggi, maka akan semakin meningkatkan ketersediaan $\mathrm{P}$ di dalam tanah. Hal ini sejalan dengan hasil penelitian yang dilakukan oleh(Sari et al., 2017). Hasil penelitian tersebut menunjukkan bahwa peningkatan Corganik tanah juga meningkatkan $\mathrm{P}$ tersedia tanah.Untuk itu, perlu dilakukan upaya penambahan organik di dalam tanah, sehingga dapat meningkatkan ketersediaan $\mathrm{P}$ untuk pertumbuhan dan produksi tanaman budidaya. Pemupukan $\mathrm{P}$ pada tanah ini harus mempertimbangkan 
Sawan: Analisis kimia tanah dan rekomendasi peningkatan kesuburan tanah

ketersediaan $\mathrm{P}$ dalam tanah dan fiksasi $\mathrm{P}$ yang tinggi, serta kebutuhan hara tanaman merupakan suatu pendekatan yang rasional agar diperoleh pertumbuhan dan hasil yang optimum, tanpa menyebabkan pencemaran unsur fosfor pada tanah dan air (Irwan \& Nurmala, 2018).

Upaya yang dapat dilakukan untuk meningkatkan kandungan kalium pada tanah di lokasi penelitian antara lain, penambahan pupuk anorganik seperti $\mathrm{KCl}$ yang mengandung unsur kalium, sehingga dapat meningkatkan jumlah untuk kalium dalam tanah. Namun pemupukan menggunakan pupuk anorganik perlu mempertimbangkan kebutuhan kalium oleh tanaman untuk dapat menghindari terjadinya kelebihan dosis di dalam tanah. Selain itu, upaya lain yang dapat dilakukan adalah pengembalian kembali sisa-sisa panen yang tidak dikonsumsi, misalnya batang jagung, daun jagung dan lain sebagainya (Tambunan et al., 2014; Widiyanto \& Sudomo, 2014). Upaya tersebut dapat meningkatkan kandungan unsur hara, termasuk unsur hara kalium.

\section{SIMPULAN}

Tanah pada lokasi penelitian di Kebun praktek Fakultas Pertanian Universitas Nusa Nipa memiliki kandungan fosfor tanah yang tinggi, kalium tanah yang berkisar antara rendah-sedang, kandungan c-organik tanah yang rendah serta kemasaman tanah yang netral.Perlu dilakukan upaya-upaya untuk dapat memperbaiki sifat kimia tanah pada lokasi penelitian, antara lain aplikasi pupuk organik, pupuk anorganik yang mengandung kalium, serta mempertahankan drainase tanah sehingga tidak terjadi penggenangan.

\section{UCAPAN TERIMA KASIH}

Penulis mengucapkan terima kasih kepada semua pihak yang telah terlibat dalam pelaksanaan penelitian ini, terutama civitas akademika Fakultas Pertanian Universitas Nusa Nipa.

\section{DAFTAR PUSTAKA}

Bustami, Sufardi, \& Bakhtiar. (2012). Serapan Hara dan Efisiensi Pemupukan Phosfat Serta Pertumbuhan Padi Varietas Lokal. Jurnal Manajemen Sumberdaya Lahan, 1(2), 159-170. http://www.jurnal.unsyiah.ac.id/MSD L/article/view/2184

Dharmayanti, N., Supadma, A., \& Arthagama, I. (2013). Pengaruh Pemberian Biourine Dan Dosis Pupuk Anorganik $\quad(\mathrm{N}, \mathrm{P}, \mathrm{K}) \quad$ Terhadap Beberapa Sifat Kimia Tanah Pegok Dan Hasil Tanaman Bayam (Amaranthus Sp.). E-Jurnal Agroekoteknologi Tropika (Journal of Tropical Agroecotechnology), 2(3), 165-174.

https://ojs.unud.ac.id/index.php/JAT/a rticle/view/6077

Gili, R. (2019). Evaluasi Kelas Kemampuan Lahan pada Kebun Praktek Fakultas Pertanian Universitas Nusa Nipa Maumere. Universitas Nusa Nipa. 
Hanafiah, K. . (2012). Dasar-Dasar Ilmu Tanah. PT Raja Grafindo Persada.

Hermanto, D., Dharmayani, N. K. ., Kurnianingsih, R., \& Kamali, S. . (2013). Pengaruh Asam Humat Sebagai Pelengkap Pupuk Terhadap Ketersediaan dan Pengambilan Nutrien pada Tanaman Jagung di Lahan Kering Kec.Bayan-NTB. Ilmu Pertanian, 16(2), 28-41. https://journal.ugm.ac.id/jip/article/vie w/2531/2265

Heryani, N., \& Rejekiningrum, P. (2019). Pengembangan Pertanian Lahan Kering Iklim Kering Melalui Implementasi Panca Kelola Lahan. Sumber Daya Lahan, 13(2), 63-71. https://www.researchgate.net/profile/S ukarman-

Kartawisastra/publication/342832480_ Jurnal_Sumberdaya_Lahan_Volume_ 13_Nomor_2_Desember_2019/links/5 f081360299bf18816102bbc/JurnalSumberdaya-Lahan-Volume-13Nomor-2-Desember-2019.pdf\#page=7

Irwan, A. W., \& Nurmala, T. (2018). Pengaruh pupuk hayati majemuk dan pupuk fosfor terhadap pertumbuhan dan hasil kedelai di inceptisol Jatinangor. Kultivasi, 17(3), 750-759. https://doi.org/https://doi.org/10.24198 /kultivasi.v17i3.19583

Mawardiana, Sufardi, \& Edi, H. (2013). Pengaruh residu biochar dan pemupukan npk terhadap sifat kimia tanah dan pertumbuhan serta hasil tanaman padi musim tanam ketiga. Jurnal Manajemen Sumber Daya Lahan, 2(3), 255-260. http://erepository.unsyiah.ac.id/MSDL/article /view/2198

Sari, M. N., Sudarsono, \& Darmawan. (2017). Pengaruh Bahan Organik Terhadap Ketersediaan Fosfor pada Tanah-Tanah Kaya Al dan Fe. Buletin Tanah Dan Lahan, 1(1), 65-71.
Soekamto, M. H. (2015). Kajian Status Kesuburan Tanah Di Lahan Kakao Kampung Klain Distrik Mayamuk Kabupaten Sorong. Jurnal Agroforestri, 10(3), 201-208. https://jurnalee.files.wordpress.com/20 16/06/kajian-status-kesuburan-tanahdi-lahan-kakao-kampung-klain-distrikmayamuk-kabupaten-sorong.pdf

Suarjana, I., Supadma, A., \& Arthagama, I. (2016). Kajian Status Kesuburan Tanah Sawah Untuk Menentukan Anjuran Pemupukan Berimbang Spesifik Lokasi Tanaman Padi Di Kecamatan Manggis. E-Jurnal Agroekoteknologi Tropika (Journal of Tropical Agroecotechnology), 4(4), 314-323.

https://ojs.unud.ac.id/index.php/JAT/a rticle/view/18019

Tambunan, S., Siswanto, B., \& Handayanto, E. (2014). Biochar Terhadap Ketersediaan P Dalam Tanah Di Lahan Kering Malang Selatan. Jurnal Tanah Dan Sumberdaya, 1(1), 85-92. https://jtsl.ub.ac.id/index.php/jtsl/articl e/view/103

Widiyanto, A., \& Sudomo, A. (2014). The Influence of Litter of Paraserianthes Falcataria ( L ) Nielsen on Arachis Hypogeae L P. Jurnal Penelitian Agroforestry, 2(1), 1-12. http://ejournal.forda-mof.org/ejournallitbang/index.php/JPAG/article/view/2 097

Wihardjaka, A. (2016). Peran Jerami Padi Dalam Memperbaiki Hasil Gabah Dan Serapan Kalium Di Lahan Sawah Tadah Hujan Di Kabupaten Pati, Jawa Tengah. Agric, 27(1), 15. https://doi.org/10.24246/agric.2015.v2 7.i1.p15-22

Yusron, M., Wati, R. S., Setyorini, D., \& Murmainah, H. (2018). Penentuan Dosis Pupuk Lahan Sawah 
Sawan: Analisis kimia tanah dan rekomendasi peningkatan kesuburan tanah

Berdasarkan Status Hara Fosfor Dan

Kalium di Lahan Sawah Kabupaten

Pandeglang. Jurnal Pengkajian Dan

Pengembangan Teknologi Pertanian,

20(2),

149-158.

http://repository.pertanian.go.id/bitstre

am/handle/123456789/8212/8275-

33523-1-PB.pdf?sequence $=1$ 